International Journal of Linguistics, Literature and Translation

ISSN: 2617-0299 (Online); ISSN: 2708-0099 (Print)

DOI: $10.32996 / \mathrm{ijllt}$

Journal Homepage: www.al-kindipublisher.com/index.php/ijllt

\title{
A Micro-macro Paradigm to Identify Simultaneous Interpreting Strategies (SISs) with Reference to -taxis Relations in UN Discourse
}

\author{
Mona AlaaEldin 8 (D) \\ Assistant Lecturer of Linguistics and Interpreting Studies, October 6 University, Egypt; Ph.D. candidate in Linguistics/Interpreting \\ Studies in Cairo University, Egypt \\ $\triangle$ Corresponding Author: Mona AlaaEldin, E-mail: mona.alaaeldin.lang@o6u.edu.eg
}

\begin{tabular}{|c|c|}
\hline ARTICLE INFORMATION & ABSTRACT \\
\hline $\begin{array}{l}\text { Received: February 11, } 2021 \\
\text { Accepted: March 20, } 2021\end{array}$ & \multirow{5}{*}{$\begin{array}{l}\text { The object of this paper is to situate simultaneous interpreting (SI) as textually } \\
\text { strategy-specific (micro level) and discursive practice (macro level) drawing on } \\
\text { Norman Fairclough's (1989) critical discourse model in Language and Power. } \\
\text { Considering its diverse nature, this article treats UN interpreted discourse as a form of } \\
\text { particularised organisational discourse where -taxis relations are surface features of } \\
\text { language at the micro level. On a deeper level, it contributes to the collective } \\
\text { ideological framing at the macro level. A micro-macro continuum substantiates a } \\
\text { more unified representation of SI through collaboration across a myriad of } \\
\text { approaches and that is where originality lies. SI is incorporated with CDA and Corpus- } \\
\text { based methods to make it possible for valid simultaneous interpreting strategies } \\
\text { (SISs)to be identified. This model helps to reveal (i) the patterns expert interpreters } \\
\text { establish to simultaneously interpret textual features, namely, hypotaxis and parataxis } \\
\text { (micro level); and (ii) the functions of interpreted textual features and whether they } \\
\text { keep oriqinal ideologies or depart from them (macro level). }\end{array}$} \\
\hline Volume: 4 & \\
\hline $\begin{array}{l}\text { Issue: } 3 \\
\text { DOI: } 10.32996 / \text { ijllt.2021.4.3.28 }\end{array}$ & \\
\hline KEYWORDS & \\
\hline $\begin{array}{l}\text { Simultaneous interpreting, } \\
\text { simultaneous interpreting } \\
\text { strategies (SISs), Critical Discourse } \\
\text { Analysis (CDA), micro and macro } \\
\text { levels of analysis, CBIS }\end{array}$ & \\
\hline
\end{tabular}

\section{Introduction}

The present review article aims to examine the previous literature deemed necessary to identify simultaneous interpreting strategies (SISs) in an Arabic-English parallel corpus of United Nations discourse. To explore the SISs expert interpreters use to interpret -taxis relations, the present article lays the theoretical grounds for a two-tier CDA of interpreted -taxis relations primarily as micro linguistic tasks, then as macro tasks where simultaneous interpreters' (SIterps) target choices could preserve or otherwise distort original ideologies. In an attempt to address the recommendations of previous research and fill the existing research gap in $\mathrm{SI}$, an interdisciplinary paradigm of Interpreting Studies (IS) and Critical Discourse Analysis (CDA) will be adopted to bring forward a more coherent analytical framework. Such a paradigm should provide rich insights into process-based research in light of the scarcity of interpreting research (IR) from and into Arabic in general, and the analysis of authentic SI performances of organisational discourse to identify linguistic-directional SISs, in particular, which is a subject of little scholarly attention. The nature of SI as a multi-faceted and demanding task has attracted the interest of many an interpreting scholar whose research approaches reinforced interdisciplinarity to investigate SI (for example, Gile, 1995; Massaro \& Shlesinger, 1997; Moser-Mercer, 1997; O 'Brien, 2015; Rinne et al., 2000; Sawyer, 2004; Seeber, 2015).

The philosophy behind the choice of the United Nations General Assembly (UNGA) as the sample of discourse under analysis is twofold. Firstly, the UN is the international organisation solely responsible for the maintenance of international peace and security, wherein the General Assembly (GA) lies; the centre of the UN system and "the chief deliberative, policy-making, and representative organ" as recognized in the Millennium Declaration (MD) (UN, 2000). Secondly, the UN is a multi-national, monocentric and hierarchical organisation according to Fairclough's CDA model (1989) whereby strategic positions, power and ideology are dynamic in well-formulated discourse, which is a key parameter to identify SISs.

A scholarly thirst for a more profound knowledge of SI intricacies has brought forward a number of original approaches, one of which is Gile's Effort Model (1992, 1997), which has been generally taken to influence an interest in process studies in SI with a focus

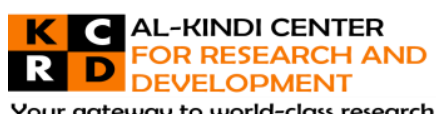

Your gateway to world-class research

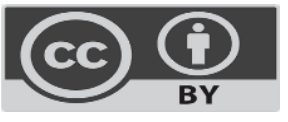

Published by Al-Kindi Center for Research and Development, United Kingdom. Copyright (c) the author(s). This open access article is distributed under a Creative Commons Attribution (CC-BY) 4.0 license 
on enabling interpreters to "select appropriate strategies and tactics," maximising Processing Capacity (PC) in a difficult SI situation (1992, p. 191). In this sense, coping strategies ascribe to lifting memory overload and the linguistic inconsistencies sparking from unnatural simultaneity, different directionality and message redundancy.

There is now much evidence that with the zoning interest in studying special linguistic features of interpreted discourse, a parallel surge of Corpus-based Interpreting Studies (CIS) has erupted. Baker (1995) and Shlesinger (1995) suggested the use of parallel corpora, that is, bilingual collections of original texts and their aligned interpreted versions, to reflect on "discourse analytical and textlinguistic tools" (Shlesinger, 1995, p. 193) because corpora provide a reliable basis for the systematic investigation of SI features.

An often less prioritized, yet original and highly significant is addressing interpreted -taxis relations as markers of cohesion within a micro-macro CDA. Such a framework supports Shlesinger's seminal take on cohesion in SI as it is "the network of relations which allow us to interpret a text by providing links between its various elements" $(1995, \mathrm{p}$. 193). This suggests that failure to handle links properly shall render interpreted discourse incomprehensible or inappropriate. The purpose of this original approach in particular is to demystify the SI of parataxis and hypotaxis, cohesion and discourse salience criteria through identifying textual, directionalspecific and discursive patterns. More specifically, the study of hypotaxis and parataxis establishes significance in the process of SI due to the Slterps' tendency to segment input based on clauses rather than longer stretches of discourse, in attempt to accelerate processing of input and alleviate cognitive load (CL) (Davidson, 1992; Goldman-eisler, 1972). For that, a great deal of what governs the processing of -taxis relations is on-the-spot clause complexing and segmentation.

In parataxis, clauses are connected by a coordinating conjunction; thus, the inter-relation is that of continuation, whereas in hypotaxis two clauses of different statuses conjoin with one being main and the other is subordinate to it, which suggests a rank shift (Halliday, 1985). Conjunctive signposts express a deluge of relations, which should guide SIterps towards the anticipation of content and structure, and furnish the audiences to establish expectation of content, order and purpose; thus, allowing for a global frame of ideology with socio-cultural manifestations to emerge.

The article will present the main theoretical tenets put forward by IS scholars to show the interplay between diverse micro textual features including cohesion markers and the macro interpretability of power and ideology in UN discourse. It will also address the previous literature on the significance of SISs in refining an SI product and the potential inclusion of corpus-based interpreting analysis methods in the identification of SISs.

\section{Methodology}

Since the purpose of this article is to lay the theoretical foundations for an interdisciplinary examination of -taxis relations as simultaneously interpreted into English and deliver valid SISs, the following table includes a selection of the sources such as the databases, the journals, the dissertations and the websites to achieve the aim mentioned above. The current paper includes high impact journals with different scopes such as interpreting research, the study of cognition and processing, Arabic and English syntax, critical discourse analysis, international relations, political and organisational discourse, and so forth.

\begin{tabular}{|c|c|c|c|}
\hline Databases & Journals & $\begin{array}{l}\text { Disser } \\
\text { tations }\end{array}$ & Websites \\
\hline Scopus & & $\begin{array}{c}\text { Dar } \\
\text { Al-Mandumah }\end{array}$ & AllC \\
\hline ScienceDirect & Cortex 99 (2018) 243-257 & $\begin{array}{l}\text { ProQu } \\
\text { est Information } \\
\text { and Learning }\end{array}$ & UNGA \\
\hline \multirow[t]{5}{*}{ Sage } & $\begin{array}{l}\text { European Journal of International } \\
\text { Relations 2015, Vol. 21(4) } 887-910 \\
\end{array}$ & & \\
\hline & $\begin{array}{cc}\text { International } & \text { Journal } \\
\text { Bilingualism (2012) } 16(2) & 228-242 \\
16(2) 183-197 & \\
\end{array}$ & & \\
\hline & $\begin{array}{l}\text { Millennium: } \quad \text { Journal of } \\
\text { International Studies (2012) Vol. 41(1) } 65 \text { - } \\
90\end{array}$ & & \\
\hline & $\begin{array}{rrr}\text { Discourse \& } & \text { Communication } \\
2011 \text { Vol. 5(4) } 393-412 & \\
\end{array}$ & & \\
\hline & $\begin{array}{l}\text { Cooperation and Conflict: Journal } \\
\text { of the Nordic International Studies }\end{array}$ & & \\
\hline
\end{tabular}




\begin{tabular}{|c|c|c|c|}
\hline & Association (2009) Vol. 44(4): 355-377. & & \\
\hline $\begin{array}{l}\text { Translation Studies } \\
\text { Bibliography }\end{array}$ & $\begin{array}{l}\text { Translation \& Interpreting } \\
\text { (2017) Vol } 9 \text { No1 } \\
\text { (2016) Vol } 8 \text { No } 2 \\
\end{array}$ & & \\
\hline \multirow[t]{4}{*}{$\begin{array}{l}\text { Academy } \\
\text { Publication }\end{array}$} & $\begin{array}{l}\text { Theory and Practice in Language } \\
\text { Studies, January 2016, Vol. 6, No. 1, pp. } \\
\text { 164-170 }\end{array}$ & & \\
\hline & $\begin{array}{l}\text { Theory and Practice in Language } \\
\text { Studies (2011) Vol. 1(11) pp. 1479-1487 }\end{array}$ & & \\
\hline & $\begin{array}{l}\text { Frontiers in Psychology (2015), } \\
\text { Vol.6 (1590) }\end{array}$ & & \\
\hline & $\begin{array}{l}\text { European Journal of Cognitive } \\
\text { Psychology, 2002, } 14 \text { (3), 353-369 }\end{array}$ & & \\
\hline Érudit & Meta (1996) Vol. 41 (1), 118-138 & & \\
\hline \multirow[t]{3}{*}{ Taylor \& Francis } & $\begin{array}{l}\text { Critical Discourse Studies (2015) } \\
\text { Vol. } 12 \text { (2) } 187-205\end{array}$ & & \\
\hline & 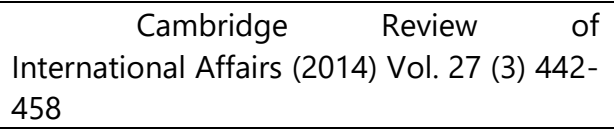 & & \\
\hline & $\begin{array}{l}\text { Rhetoric Society Quarterly (2012) } \\
\text { Vol. } 42 \text { (5) } 424-449\end{array}$ & & \\
\hline Springer & Int J Semiot Law (2015) 28, 559- & & \\
\hline JSTOR & $\begin{array}{l}\text { Global Governance (1997) Vol. } 3 \\
\text { (3) pp. 269-276 }\end{array}$ & & \\
\hline
\end{tabular}

Table (1): A sample of the databases and journals used in this paper

\section{The Interplay of Language, Power and Ideology in UN Discourse}

In Language and Power (1989), Fairclough introduced a systematic framework for the critical analysis of language across a plethora of social contexts with organisational metrics of power and ideology being thought of as ubiquitous representations of social realities. Since then, methodologically, CDA has been accepted as a move that transcended the orthodoxies of analyses restricted to an individual genre and stimulated other theories such as multimodal CDA to approach discursive socio-linguistic investigations. The three points of departure for Language and Power (1989) are language, social theory and the critical analysis of discourse. With that, language is not autonomous; it is subject to societal and organisational dynamics that have a say in manipulating and (re) the emergence of ideologies and powerful social practices. Discourse is powerful too, because in a meditated exercise of power, language would justify or, perhaps, legitimize the tacit (re)ordering of ideological strata. Thus, it is incumbent to investigate textual features in organisational discourse where inequalities inflicted by the powerful can possibly be detected. Fairclough (1989) designated the connection between language and the unequal relations of power and ideology, firstly for the purpose of changing the misunderstanding that language is not powerful enough to instigate change; secondly, for raising the consciousness of those who do not know or are not aware that they can be manipulated by language.

Fairclough stated that "the role of language [is] in the exercise, maintenance and change of power" (1989, p. 12). Then ideology, just like power, could simply be in the various assumptions implicit in daily normal recurrences of the language we use. In order for ideology to be fixated, it requires the power of recurrence. Therefore, ideology and power are interrelated because ideological assumptions stem from particular social conventions that have become common sense or taken-for-granted and that is itself power. The taken-for-grantedness property, transmitted through language, legitimises existing social conventions and maintains a hierarchy of power. As noted previously, Fairclough proposed that the ideological nature of language lays the foundations for "the exercise of power, [which] in modern society, is increasingly achieved through ideology, and more particularly through the ideological workings of language" $(1989$, p. 2). For example, the linguistic mechanisms through which ideology creates consent rather than coercion highlight how some textual features could position the less powerful and predispose them to be dominated by the powerful who would then get the desired inferences, restructure and control collective ideologies (Fairclough, 1992; Jørgensen \& Phillips, 2002). This collectivist view reflects Fairclough's (2001, p. 2)definition of ideology as "a means of legitimizing existing social relations and differences of power, simply through the recurrence of ordinary, familiar ways of behaving which take these relations and power differences for granted."

In Faircloughian discourse model, it is indispensable to show the hidden determinants, relations and effects embedded in the social system of interaction where language is used. The marriage of socio and linguistic conventions paves the way for a mosaic of power relations as prototypically proposed by de Saussure and Foucault whose contributions have brought valuable insights 
to the development of CDA and the modern forms of exercising power in discourse or more precisely, discourse in power as Foucault argued:

Power is the capacity to impose and maintain a particular structuring of some domain or other - a particular way of dividing it into parts, of keeping the parts demarcated from each other, and a particular ordering of those parts in terms of hierarchical relations of domination and subordination. (Foucault, 1998, as cited in Fairclough, 2013)

The very hierarchical relations of domination and subordination appear in structural ordering in one sense, and more pressingly in another, as tools of ideological framing. Holzscheiter (2011) proposed that CDA serves as a powerful tool to analyse the discourse of International Relations (IR) and a means of promulgating global organisational norms to seize institutional power on a macro level. This very multi-dimensionality of CDA helps to unfold struggles for power and norm-making processes through fixating the dynamics of meaning. Though the United Nations (UN) is an apostle of a democratic system of global governance, its quest to exercise lawful power-by which main organs, agencies or Member States (MS) abide under the Charter and with the use of language-specific means-is unwaning too. In essence, the regularisation of norms is often followed by their globalisation, which eventually empowers the UN. So, for example, the UN term of global public goods is packed with incoherence and abstractions yet it has been stressed and foregrounded in UN discourse to create a sense of collective global interest regardless of its particular context (Long \& Woolley, 2009). As with the way language shapes social realities, Fischhendler and Katz (2013) studied UN resolutions on sustainable development observing the use of the term security and found that it primarily adopts a personal view of safety rather than a global one almost every time it is mentioned. Moreover, Scotto di Carlo (2015) concluded that the United Nations Security Council's (UNSC) resolutions during the Gulf War emphatically stressed the power of weasel words which are open to flexible interpretability and double meanings; thus, the UNSC is provided with the chance to hedge and avoid direct stances. Monte (2016) argued for a similar conclusion in which the control of UNSC language is itself power resulting from the interaction between power politics and international law for the aim of prioritisation and idealisation. In addition, Shepherd (2015) investigated the United Nations Peacebuilding Commission's (UNPB) resolutions and argued that international organisations exercise discursive practices to create stability in meaning. In this case and during the drafting phase, the role of civil society representatives' changes from that of consultants to partners.

A negative view of the role played by organisational discourse attributes elusiveness, and strategic manipulation as main properties of UN discourse. Thus, it is marked by an indeterminate nature to hide bias and a tendency to (re)create collective identity through questioning or falsifying long-time held public perceptions, in other words, what is referred to as hegemonialisation (Childers, 1997; Herschinger, 2012). Conversely and in Thérien and Dumontier's (2009) account of UN discourse, the UN has managed to actually foster global democracy, that is, governance based on the configuration of high and low powers to match the loud tempo of an ever-changing geo-political world. Such findings report that the recurrence of a unified representation of textual features could help in the establishment of organisational/UN ideology across different contexts.

\subsection{UN Discourse: The Impact of Taken-for-grantedness on Instilling Organisational Ideology}

Functionally, CDA aims to lay bare the gap between the explicit and the implicit in any given discourse by focusing on the textual features that organisations and political actors use to ground their ideologies and disseminate them on a wide scale. According to Fairclough (2003) and le Roux and Adler (2016) language use in organisational discourse shows a recognisable pattern, which is the result of a systematic practice and deliberate socio-political relations that construct collective identity. Such systematic practices produce taken-for-grantedness in which textual features transform the disputable into a common sensical. Upon inspection, this technique helps map power relations and ideological positions and thus reform the inequalities embedded in discourse. More specifically, the power of taken-for-grantedness builds up the following sequence: firstly, it bridges differences among audiences by attracting commonalities, secondly, it consolidates solidarity, especially in larger populations and finally, it gives a small room for opposing views to challenge the majority, isolating them; hence, becoming less powerful.

Taken-for-grantedness appears to be far from unanimity within the realm of UN discourse. The study of Binder and Heupel (2015) showed that MS of the UN had a sharp ideological divide about the UNSC's unquestionable legitimacy to issue binding resolutions, given its exclusive decision-making and negative evaluative assessments of its procedures. The impact of taken-forgrantedness on the dissemination of political stereotypes is also the cornerstone of Simon-Vandenbergen et al's model (2007) which suggested that politicians' utilisation of different textual features to establish taken-for-grantedness in three different cultures brought forward similar reactions and conventionalised certain ideas. Conventionalisation is instrumental because it passes on acceptable standards and thus constructs ideology. Similarly, McEntee-Atalianis (2011) analysed metaphor in the statements of the UN Security-General and concluded that metaphor is strategically used as a tool of polarisation and legitimisation of power. This supports the conclusion of Cheng (2012) who reported that the use of modality for self-positioning helped in evidence-building and ideological reconstruction of the distorted image of the US administration as evident in Colin Powell's 2003 pre-war on Iraq statement in the UN. Likewise, Schnurr et al. (2014) illustrated that the US's claim for leadership is 
dynamically exercised via a series of (inter)discursive normative practices that foreground actors and terms based on urgency, which is yet another attempt to refine the US worldview and its discourse of nuclear non-proliferation in a number of UNSC resolutions. On the negotiation of meaning in UNGA discourse, Radu (2013) argued that the resolutions of UNGA on cybersecurity formed a generic representation of informative guidelines and lacked specificity. Set against the backdrop of the UN as a talking shop, Panke (2014) studied UNGA resolutions and found that a large number of resolutions had consecutively reoccurred in prior UNGA sessions.

\subsection{Taxis Relations Defined in English and Arabic}

Foucault (1996, p. 410) stated that "power is relations; power is not a thing, it is a relationship between two individuals, a relationship which is such that one can direct the behaviour of another or determine the behaviour of another." The making and recycling of ideology positions audience purposefully which would later regularize relations, create shared common sense. Thanks to language opacity, social control and dominance are produced and reproduced to construct fresh ideologies, which are defined as:

Basic frameworks of social cognition, shared by members of social groups, constituted by relevant selections of sociocultural values and organized by an ideological schema that represents the self-definition of a group. Besides their social function of sustaining the interests of groups, ideologies have the cognitive function of organising the social representations (attitudes, knowledge) of the group, and thus indirectly monitor the group-related social practices, and hence also the text and talk of members (Van Dijk, 1995, p.248).

The focus of analysis thereupon should go to the how not the what as it creates a connection that transform a text into a discursive practice. Investigating UN ideology, thus, is essential for the fact that ideology is a holistic intellectual environment that draws attention to the nature of public concepts as systematically interwoven to construct new orders (Thérien \& Joly, 2014). Mainstreaming ideology with discursive practices of what is assumed to be correct is realised through the formation of a globalised social-cognitive model embedded in specific discourse orders. Upon inspection, the interrelationship between micro textual analysis and a macro sociocultural context would be unearthed (Van Dijk, 1988, 1991). For example, Grausam (2005) found that fundamentalist discourse, whether Christian or Islamic, uses similar discursive strategies to maintain control on a macro level. So, Islamist discourse is more foregrounded towards the internalisation of coherence within local communities via emotionally and religiously loaded concepts. At the same time, global political conflicts are presented as the cause of instability which polarises collective consciousness and legitimises the use of violence as a defence mechanism.

Even though the grammaticality of hypotaxis and parataxis appears to be clear in the history of linguistics, evasiveness of some functional aspects still holds true. Lehmann (1988) offered a rather practical solution that allows parataxis and hypotaxis to be used interchangeably with the more common coordination and subordination. Both syntactic constructs denote part of a more complex unit within which they are clause- and relation-oriented. So, subordination/hypotaxis holds for dependency irrespective of the nature of subordinates and coordination/parataxis for parallelism. If a sentence is made up of two clauses, they are either connected via parataxis or hypotaxis (R. Huddleston et al., 2002). Parataxis distinguishes equal constructions; this quality is based on the weight and type of grammatical constituents. Since the term conjunctions might be confusing, though used in most formal grammar books, the terms coordination and subordination, if used, will refer to parataxis and hypotaxis, respectively, and the term conjunctive will refer to a coordinator or subordinator. Shiffrin (1987) proposed that discourse markers (DMs) are a problematic term due to multi-functionality, optionality, and syntactic diversity. For example, Halliday and Hasan (1976), Baker (1992) and Alazzawie (2014) investigated and or wa- in terms of additive, temporal, or adversative multi-functions in English and Arabic, concluding that the constituent structures behave grammatically in a way that affects the functions of wa- as conjunctive, associative or initial. This aspect was explored by Bott et al. (2009) in the study of and as one of the most common coordinators, stressing that though and is presumed to have a simple fact-conditional meaning or rule-based operationalisation, the type of discourse relation, order and implicature control its interpretive meaning, the relation among conjoined clauses and overall coherence of discourse.

The logic governing parataxis and hypotaxis is unequal versus equal relations. For example, if $B$ is subordinate to $A, A$ is of the highest position within the hierarchy of a subordinate construction. A solid relation of dominance-dependence is established in which the presence of a subordinator is based on multilateral recognition of hierarchy. In this case, roles in a given frame cannot be switched, so A cannot be subordinate to $B$; it is always a head. But if joined clauses or sentences are equal and presumably of the same status, this is a paratactic construction. In unequal relations, co-existence is crucial because the subordinate clause complements the main clause. In this sense, Lang (1984) argued that hypotaxis is the making of a superordinate clause, which Trask (1993, p. 286) defined as a "phenomenon by which one clause forms a constituent of another clause." Therefore, a subordinate clause cannot represent a sentence; it is grammatically and functionally impossible to have such a construction (Huddleston, 1988). Engelkamp and Rummer (2002) studied hypotaxis as a tool of unifying memory through its 
multidimensionality that incites immediate recall compared to parataxis. The obvious prominence of some actors or institutions reflects that clausal asymmetry plays directly to ideological and social defining. Thus, -taxis relations are basically syntactic notions that become more salient at the macro level of social and ideological analysis.

Parataxis is realised when two syntactically equivalent constructions are placed in one unit. Their syntactic sameness enables them to play an equal semantic role. If one of the parts is more salient or important than the other, it is out of the equality equation (Haspelmath, 2004). Thus, parataxis is a non-headed construction. The different elements making parataxis are coordinates and the words that mark this relation are coordinators. Though it is generally known that coordination occurs between similar syntactic constituents, still non-similar constituents could make coordination which explains that sameness is mainly meaning substantiated. According to Lehmann, "coordination is a relation of sociation [that is, non-dependency] combining two syntagms of the same type and forming a syntagm which is again of the same type" $(1988$, p. 182).

The most distinctive property of parataxis is the infiniteness of grammatical coordinates in one sentence, for example, they are grouped according to weight, colour, shape, height and complexion. Parataxis could occur between two functionally similar constructions instead of similar syntactic ones. It is thus "individually admissible at a given place in a sentence structure if the coordinates have the same function... each coordinate can occur on its own with the same function" (Lehmann, 1988, p. 201). Though two grammatical elements can be of the same category, ungrammaticality can result from the failure to satisfy the functional aspect rendered true by parataxis.

The marking of parataxis is realised in the following three ways:

\begin{tabular}{rcc}
$\begin{array}{r}\text { i. } \\
\text { Syndetic }\end{array}$ & Simple & $\begin{array}{c}\text { You need celery, apples, walnuts and } \\
\text { grapes. }\end{array}$ \\
ndetic & Polysy & $\begin{array}{c}\text { You need celery and apples and walnuts } \\
\text { and grapes. }\end{array}$ \\
\hline iii. & Asynde & You need celery, apples, walnuts, grapes. \\
\hline tic & & \\
\hline
\end{tabular}

Table (2): Markings of Parataxis (Huddleston \& Pullum, 2007, p. 202)

Simple syndetic allows for a coordinate that takes the final position in the sentence. In contrast, asyndetic coordination is simply the complete absence of any coordinates. Polysyndetic coordination utilises more than one coordinate which means that more coordinates could be marked. The two most central and common coordinators are and and or, whereas but is also a coordinator that works with binary coordination. Hence, there is no specific order of coordinates, which entails that reversing the order will not affect the functionality of the sentence. However, in symmetric coordination, the logic of the sentence is interrupted which may affect the interpretability and acceptability of the sentence.

Classical Arabic grammarians addressed the definition of sentences, which is "self-contained meaning groups" (Holes, 2004, p. 251). To put it in a grammatical frame, the constituents of an Arabic sentence are a predicate and a subject (freestanding or dependent). But a major aspect that differentiates between the Arabic sentence and the English one is that the former lacks punctuation, which necessitates accurate interpretability. To this day, a clear system of Arabic punctuation is almost absent which lends itself to impressionistic and idiosyncratic behaviour on part of grammarians.

As a mark of elevated writing, Beeston (1970) argued that parallelism as featured through parataxis is a common stylistic feature of Arabic. On the ratio of compound and complex sentences in original Arabic and English translated texts, the study of Prof and ljam (2013) revealed that Arabic utilises parataxis more often and that the use of hypotaxis is perceived to be a sign of textual sophistication and relational clarity in English translated texts.

The Arabic tendency towards aesthetic parallelism is maintained in SI too, however, parallelism of Arabic original discourse becomes somehow problematic during the process due to the impact of other prosodic variables on building inter-sentential relations and discursive coherence. Hence, unlocking clausal or intra-sentential relations is essential for a comprehensive interpretation of discourse to be made (Dickins et al., 2017). Drawing on that, a lack of a standard system of punctuation is thus substituted with a system of textual chunking in SI that is based on "coordinating and subordinating conjunctions that perform the dual role of signalling the beginnings and endings of sense groups and indicating the nature of the logical or functional relationships between them" (Holes, 2004, p. 251). Also, Enani (2020) identified restructuring as a strategy of textual chunking which could render discourse appropriate and cogent to the target audience. Orally, hypotaxis also could be realised through prosodic means such as clause preposing, a technique in which components of a spoken message switch original positions. 
In event-oriented reporting, the Arabic sentence tends to strongly utilise the VSCOMP order as it highlights the doer of the action, the action itself and how it is done. A more explanatory account of already definite agents or rather 'entity-oriented' text would find an SVCOMP order more precise as it carries new information about key terms in a way that describes operations or structures (Holes, 2004). Essentially, SVCOMP sentences address states of a definite subject, not actions. Affected by the predominant English inclination for SVCOMP order, many Arab writers make use of it, regardless of message type. Unsurprisingly, VCOMPS is infrequent because grammatically, it consists of a definite complement and an indefinite subject. In such situations where the subject is anonymous, it should be predicated by a known complement, for example, sakana fil madinati akhi. This implicates a position shift of the subject; however, a final position equally reflects an emphasis of the subject in contravention to being initially positioned. From a Modern Standard Arabic (MSA) perspective, heavier lexical series making up the Subject or Complement are placed to the lighter side of the sentence, usually at the right. For a combination of information, rhythmic and auditory reasons, the use of VCOMPS highlights that definite is first in a bid for foregrounding new textual information.

In the same context, (Holes, 2004) identified three major textual developments in MSA: a strong tendency to utilise a variety of connectives, a move towards hypotaxis rather than parataxis, and finally a particular dependency on adverbial clauses as a vehicle for the transmission of logico-semantic relations. According to (Enani, 2020) parataxis is indeed a syntactic feature of written Arabic that has elevated its users and has been dubbed a benchmark of excellence in Arabic oratory too, as it touches on the textual and stylistic flavour of discourse. For example, early Arabic rhetoric considered monostichs, poems of independent paratactic stanzas, a sign of exquisite craftsmanship. However, a contemporary account of Arabic discourse shows that an operative clause of a given Arabic UN resolution that is placed next to a preamble, utilises, in principle, hypotactic tools to absorb dense semantic content. Generally, SIterps-as producers of oral discourse-are inclined to replicate or imitate original taxis relations regardless of any paratactic considerations.

Though intersentential relations between juxtaposed clauses or sentences seem simplistic, a great deal of parataxis interpretive attempts are governed by the receiver unlocking the conflicting functions of coordinators (as shown below). Syndetic coordination, the frequently encountered means of linking sentences in Arabic, is formed through the use of coordinating particles, namely, wa, fa, thumma, aw/ am and bal. Broadly speaking, they express a basic set of relations consisting of addition and, sequence then, adversative emphasis rather, result so, and disjunction or. Unlike Arabic which lacks the facility of sequential description with no visible conjunctives, in English syndetic and asyndetic coordination are equally functional, rhetorically and grammatically for example,

(1) I went to the mall, met some friends and bought a dress.

dhahabtu ila Imarkaz Itijarei wa qabaltu ba'ad lasdeqa' wa eshtaraitu fustanan

wa-

As the most commonly used Arabic coordinator, wa- shows great flexibility and susceptibility to multiple logico-semantic functions although indigenously marked by addition. It is normal to find wa- as paragraph- or sentence-initial except in the first paragraph of an article made up of many paragraphs. Wa-is clitic in that it should be prefixed to the following word. Based on Holes' (2004) classification of paratactic conjunctives, a typology of the functions of wa- illustrated by way of original and interpreted examples, occasionally modified, from AEPIC, the Arabic-English parallel interpreting corpus compiled from statements of UNGA General Debates from 2011 to 2015 is illustrated below:

\section{Static Description}

وآخر مثال على ذلك، التفجير الإرهابى الذي جرى مؤخرا في دمشق بتاريخ 2012/9/26 ....ـولا نستغرب فشل

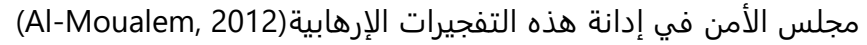

[And] The most recent example of this is the terrorist bombing that recently took place in Damascus on

the 26th of September in 2012... And there is no surprise that the Security Council has failed to condemn this.

$w a-$ acts as a concatenation device. In SI, an audible pause emulating a full stop and marking the end of a sentence gives significance to the initial wa- which signals the beginning of the next sentence.

\section{Narrative Sequence}

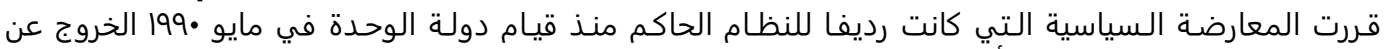

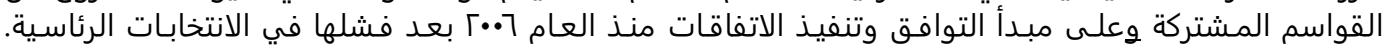

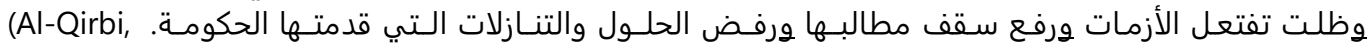

The political opposition that has been one of the main components of our system since the establishment of the State of Unity in Yemen in May 1990 decided to relinquish all common denominators and rejected the principle of consensus [and] refusing to implement the agreement that we reached since 2006 following its failure in the 
elections.

Here, wa- is time-bound and has the same function of then as it connects a series of events in a sequence to further expand intrasentential relations of succession.

\section{Simultaneous Action}

(4) مؤكدين للعالم أن إرادة الشعوب لا تنكسر وهي قادرة على منح السلطة وأيضاً على نزعها ممن

يسيئون استغلالها. (Fahmy, 2013)

They showed the world that the will of the peoples cannot be broken, that it can grant authority [and] just as it can remove it from the hands of those who abuse it.

Two actions or more are simultaneous; they happen simultaneously, which indicates that both have an equal footing as further clarified by the verbal and nominal semantic choices realised in the conjoined clauses.

\section{Circumstance}

إننا في إفريقيا نتطلع إلى تعاون مثمر مع شركائنا يفتح الأسواق العالمية أمام منتجاتنا الزراعية

$$
\text { ويساعد على تطوير قدراتنا في ميادين البحث الزرياعي. نتئ (Aziz, 2014) }
$$

In Africa, we aim for fruitful cooperation with our partners, thus opening international markets to our agricultural products and that's allowing the development of our capacities in the sectors of agricultural research.

The logico-semantic relation herein is co-occurrence. From that, capacity building can become true when fruitful cooperation happens. In a slight departure from equal prominence, the main action is conditioned by surrounding circumstance thus giving it particular significance.

\section{Adversative}

والحرية الموجودة اليوم في العراق هى حرية أتصور كثير من شعوب العالم تتطلع إليها...

That by itself shows that there is a political sphere for a free/ freedom of expression of opinion.

[And] Our problem in Iraq is not an internal problem.

wa- links two covertly or overtly contradictory clauses. Without adverbial backing, it has the meaning of but, especially when the second clause imposes a sort of limitation on or reflects inconsistency with the first.

fa-

طغت المعاناة الإنسانية المتزايدة على ما سواها من مشاهد الأزمة المتعددة. فِأعداد القتلى فئس

والجرحى تتضاعف وأعداد اللاجئين والنازحين في الداخل والخانية المتزارج على في ازدياد مستمر. (Al-Sabah, 2015)

The aggravated humanitarian suffering is overwhelming the other multiple parameters of the crisis, [so] the numbers of dead and injured are multiplying, and the numbers of the refugees and displaced/ internal displaced persons are constantly increasing.

Compared to wa- which is neutral in its conjunctive nature within which pieces of evidence are almost linked monolithically, $\mathrm{fa}$ - shows the logico-semantic relationships of conclusion, result, slight topic shift, sequence and contrast. In this example, fa- marks a relationship between two clauses, such that it highlights a condition 'aggravated humanitarian suffering' upon which 'the increasing number of dead and injured' is a consequence of.

\section{thumma}

كما تسنى لتونس في إطار استكمال مراحل المسار الانتقالي تنظيم انتخابات تشريعية ثمئم رئاسية

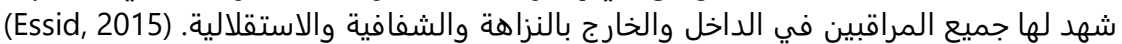

Similarly, and in the framework of the transition process, we succeeded in Organising legislative [then] and presidential elections. All observers, within and outside of the country bore witness to the integrity, the transparency and independence over the course of the elections.

Just like one of the functions of wa-, thumma signals a sequence. Adding to that, it indicates a change in direction or diversion of the normal proceedings of an event. Sometimes, it is a staging marker and thus introduces a new 
development. Here, it is sequential in original Arabic but has changed to and in SI which explains that multifunctionality of $w a$ - is not only restricted to Arabic and that the sequential sense of and is more flexible compared to then.

\section{aw and am}

Both coordinators signal a disjunctive function. aw is used with synonyms or near synonyms in affirmative or interrogative statements. Just like $w a$-, it coordinates different elements across all textual levels. am appears with interrogatives and expresses a list of exclusive possibilities to choose from. If the paratactic sentences are negative, wa- is used with the negative particle la- to give the meaning of nor.

لن نسمح لأي أحد أو أي ظرف أو أي جهة بإطفاء أنوار الحرية والديموقراطية والتنوع والتعددية

والعلم وحقوق الإنسان في لبنان. (Salam, 2014)

We shall not allow any person, [or] any circumstance, or any party to extinguish the beacons of freedom, democracy, diversity, pluralism, knowledge, and human rights in Lebanon.

In this example, aw conforms to the flexible generic nature of surrounding coordinates. Polysyndetic coordination, illustrated in the example mainly betokens exclusive options, such that 'either... or' and 'neither... nor,' which is realised in MSA by imma...aw or imma... wa.

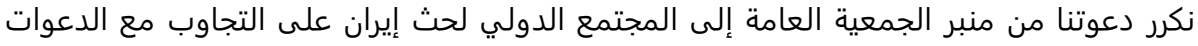

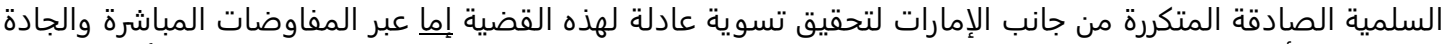

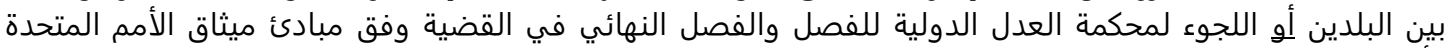

وأحكام القانون الدولي. (Al-Nahyan, 2014)

We renew our call from this platform to the international community to urge Iran to respond to the repeated peaceful, sincere calls of the United Arab Emirates for a just settlement to this issue, either through direct serious negotiations between the two countries or by referral to the International Court of Justice to settle this dispute finally in accordance with the principles of the United Nations Charter and the provisions of international law.

\section{bal}

As a coordinator, bal fulfills a conflicting dual role that affirms a primarily stated proposition and contravenes it in an attempt to introduce a new proposition that adds extra accuracy or detail to the previous one. The example below shows that in interpreting, a single coordinator cannot express this duality, so interpreters select between indeed and but the most functionally appropriate conjunctive.

فتجارب الأمم وتاريخ الشعوب تؤكد أن التسويات غير العادلة لم تدم بل كانت مقدمة لصراعات

$$
\text { جديدة/ لصراع جديد. (Al-Thani, 2013) }
$$

In fact the experiences of different nations and peoples confirm that unjust settlements do not endure [indeed] but they were just pretexts for new conflicts.

As the other means of clause linkage, following is an account of hypotaxis in MSA, which betokens more sophisticated use of conjunctives in MSA compared to coordinated sentences which are more typical of relaxed or uneducated speech.

\section{Hypotactic Sentences}

In MSA, there are four different types of dependent clauses consisting part(s) of a main clause. Apart from adjectival clauses which have a quite clear function, sometimes, the functions of some of the three clauses intertwine.

\section{Nominal Clauses}

Generally speaking, these clauses are weak and syndetic. A complementizer links the nominal clause to the main clause of which anna or an are famous examples. Mostly, a nominal clause could be positioned in the complement or the subject slot of the main sentence with some stylistic restrictions. anna is followed by an accusative subject which, if a pronoun, is suffixed to it, though subjects differ based on factuality and aspect. Therefore, anna is followed by the S(V)COMP order, and conversely an by VSCOMP or VCOMP. If the action is factual whether complete or not, anna + S(V)COMP is more common, while non-factual, an +VS(COMP) is the norm. A verbal noun construction for example, raheeluhu could suggest 'he will go,' 'he has gone' or 'he went' thus factuality and aspect become a bit implicit which could be better presented within a nominal clause. Building on that foundation, textual decision making in Arabic should not be controlled by stylistic preferences but rather by explicitness and unambiguity. Although syndetic coordination is common across varieties of Arabic, a distinction between syndetic and asyndetic coordination becomes salient in which verbs of cognition are used with the first and desiderative or modal verbs with the latter. Inna and her sisters occur in hypotactic clauses which corroborate to the logico-semantic expansion characteristic of hypotaxis. They initiate nominal clauses which are weak in nature. Interestingly, they mirror the grammatical transformation of kaana and her sisters to the subject noun of the nominal clause; however, they change the declension of the subject noun to the accusative 
case rather than the nominative. For example, inna/ anna places extra emphasis upon the truthfulness of a proposition, ka'anna shows similarity, laakinna shows contradiction where it is also a tool of repair that reverses a proposition, laita expresses vain hope, and la'alla shows hopeful expectation (Abboud \& McCarus, 1983).

\section{Adjectival Clauses}

Adjectival clauses are sentences with relative pronouns connected to the noun in the main clause; just like English, they could be restrictive or non-restrictive. These clauses are positioned after the noun they modify and with which they agree in number and gender in most cases. If the preceding noun is definite, there should be a relative pronoun, which is otherwise absent with an indefinite noun, for example, alhikayatu llatì lā nihayata lahā versus ḥekayatun lā nihayata lahā. Clause conversion is common in MSA in that verb-containing restrictive clauses could turn into participial phrases. For example, adduwalu llati ta'khudhu fi nnumūw has the same meaning as adduwalu läkhidhatu fi nnumūw.

\section{Adverbial Clauses}

\section{Time Clauses}

These clauses mainly consist of lammā, idh, idhā, mundhu, hattā as time particles. Lammā clauses are usually foregrounded when they are construed as a result of a prior completed action. On inspection, idh seems very similar to lammä; however, on the converse, idh denotes a sudden event that is happening concurrently with the action in the main clause.

\section{Purpose, Result and Reason Clauses}

A set of flexibly-positioned conjunctive particles perform the function of purpose and are grammatically followed by subjunctive verbs, namely: li, li'an, hattā and likay. fa is originally a coordinator denoting a normal consequence or result. Interestingly though, it is also a subordinator, normally if followed by a verb that expresses a desired but unfulfilled result.

\section{Concessive/ Exceptive Clauses}

A couple of concessive clauses that have the meaning of although/ despite and which denote complete or existing action include anna, ma'anna, bi/a'larraghmi min anna, 'ala anna, illā anna, byda anna and ghayra anna. The ma'anna and birraghmi min anna are flexibly positioned before or after the main clause. To such a structure, a resumptive fa-is concomitant and is main clause-initial. Most of the exceptive conjunctions with the exception of ma'anna and bi rraghmi min anna are sentence- or paragraph-initial; they perform the function of qualifying a preceding argument which is mostly located in a part that is larger than a clause (Holes, 2004). A very common exceptive conjunction in MSA media and expository writing is illā idhā which has the meaning of unless as it counts at length the reasons why something cannot be done without. An exceptive linkage could come in handy to break down the solid reasons previously listed. On closer inspection, the English coordinator of yet could do the same function of the Arabic subordinator of ghyra anna.

Holes (2004) described the importance of message order given that dependent and main clauses are appropriately-positioned strategically and stylistically to express logico-semantic relationships. Broadly speaking, main clauses include essential information and so tend to occur first and this conforms to the real logical order of things in which an event is vigorously described followed by a complementing clause. Furthermore, this explains the modern textual tendency towards clause subordination, passivisation and nominalisation in MSA which resonates with English syntactic preferences.

\section{Conditional Clauses}

In English, conditional clauses consist of a protasis, and an answering clause or an apodosis. They are logico-semantically dependent; the answering clause is the result of the conditional clause, in other words, the apodosis becomes invalid if the proposition of the protasis is not realised. In MSA, conditional particles are signposts marking real, unreal or possible conditions and in many cases, these particles share the same meanings. They are followed by a present or a past verb clause to set the condition, which is followed by the conclusion mostly expressed in a past or present verb clause or a nominal clause. in and idha are two conditional particles which have a slight difference. in expresses a shady proposition that might happen or not, although it is still possible. idhā introduces a more certain proposition but the timing is not clear. law goes a bit further in the realm of possibility as it introduces an impossible proposition. Functional particularization plays an important role in differentiating between textual and organising conditionals. Organising conditionals highlight the order and consistency of a text, whereas textual conditionals give the sense of uncertain possibility of whether a proposition can be realised or not.

For Halliday (1994) language is made up of strata; similarly, Donahue and Prosser (1997, p. 32) argue:

Discourse is viewed in terms of networks; the global or macro level and the micro or the local level which is at the opposite end of the macro. For example, the macro level may include an outline of headings or a major theme; the micro, those elements that tie or connect two sentences. The essential point is that overarching content or devices provide order for the discourse. 
The significance of a micro-macro analysis stems from connections it establishes in the micro frame and the impact of such an establishment on the macro frame, in this regard, "even single, non-contiguous sentences contribute to discourse" (Donahue $\&$ Prosser, 1997, p. 32). Without the inclusion of micro and macro levels of analysis, representation will be missing an integral part of a fair critical analysis.

\begin{tabular}{|l|l|}
\hline Discourse levels \\
\hline Textual stratum & $\begin{array}{l}\text { Elements that tie together large segments of text from paragraph } \\
\text { blocks to text sections to the whole text }\end{array}$ \\
\hline Macrolevel & $\begin{array}{l}\text { Elements that tie one paragraph segment to another segment of text, } \\
\text { paragraph, or that which forms paragraph blocks or sections of text }\end{array}$ \\
\hline Midlevel & Elements that tie adjoining sentences up to that of the paragraph \\
\hline Microlevel & \multicolumn{1}{|c|}{ Elements that form a single sentence } \\
\hline Sentential stratum & Clause level
\end{tabular}

Table (3): Discourse Levels and Textual Strata (Donahue \& Prosser, 1997)

For Charniak (1979), a frame is an ideological course of action where a new component joins in and attempts to conform to the set of ideological components already accumulated throughout the years. UN discourse is made up of micro and macro frames. The micro-frame consists of global linguistic patterns and signposts that help audiences establish expectancy of content, order and purpose.

\section{Interpreting Research Demystified}

Most of early process-oriented studies in IR endeavoured to investigate the cognitive breakdowns experienced during the process of SI, so they were mostly error-oriented (Cokely, 1984; Moser-Mercer, 1978). For example, Gerver (1976) studied memory and attention in psychological descriptions of Slterps based on information processing models and found that nonverbal factors affect Slterps' deciphering source messages such as absence or presence of speakers or audience. Likewise, MoserMercer $(1978,2000)$ explored the stages of cognitive processing during the comprehension and production of SI and concluded that expertise helps in the effective management of $\mathrm{CL}$ compared to trainee interpreters. However, cognitive constraints such as simultaneity of tasks and processing speed remained highly operational in both categories. Seleskovitch (1977, p. 28) proposed a cognitive model that viewed interpreting in terms of sense, in other words "the sensing of what is meant as opposed to knowing a language as such is the very foundation of interpretation" and thus introduced a three-step process to decipher the oral message through understanding, visualisation and sense.

Ingram $(1974,1985)$ adopted one of the early communicative models of SI based on a view of interpreting as a complex semiotic process in which the interpreter channels code-loaded meanings. Thus, the interpreter has to decode, transfer and recode multiple messages in "a single act of interpretation" (Ingram, 1985, p. 111). Drawing on a psycholinguistic approach to analyse the miscues of six interpreters, Cokely (1984) considered SIterps as mediators and offered a taxonomy of cognitive processing in SI that consists of message reception, preliminary processing, short term message retention, the realization of semantic intent, determination of semantic equivalents, phrasing a message syntactically and production.

More recently, a number of cognitive studies in IR looked at the ways working memory (WM) and expertise, in particular, affect their capacities and other aspects of interpreting performance, such as articulatory suppression (AS). Baddeley $(2007,2010)$ defined AS as the production of a verbal output that is irrelevant to the ST due to the WM's inability to simultaneously process the ST and rehearse a verbal task prior to actual production. Köpke and Signorelli (2012) studied methodological aspects to assess WM during $\mathrm{SI}$ and found that expert Slterps rely on WM less than novice Slterps in serial and free recall tasks. Tzou et al. (2012) and Injoque-Ricle et al. (2015) measured WM span and AS against SI performance and reported a positive correlation between them manifested in better coping and quality performance in highly proficient L1 L2 Slterps who are exposed to consistent formal training.

When two languages are non-selectively and simultaneously activated in $\mathrm{Sl}$, cognitive control/ executive functioning processes become activated as well (Dong \& Lin, 2013; Dong \& Zhong, 2017). Simultaneity is one of the major sources of SI constraints, which brings up questions about the means or the strategies that Slterps could use to overcome challenges of simultaneity, particularly CL. According to Gile (1999), the first stage of interpreting is the heaviest with mental load and saturation problems, which requires the operationalisation of coping cognitive strategies. Deducing such coping strategies is not possible without expertise, demonstrating higher coordination of dual tasks and consistency of patterns (Strobach et al., 2015). To investigate the effect of speaking speed as an independent variable on expert Slterps' perception of SI difficulty. Barranco-Droege (2015) 
concluded that time compression of the same speech results in slower cognitive processing and negatively affects quality performance. In a pilot experiment, Chernigovskaya et al. (2016), showed that SI instigates a change in executive functions and increases levels of stress as it is considered a kind of emotional disadaptation-a situation that often requires strategic solutions based on high expertise. Hervais-Adelman et al. (2017) proposed that domain-general cognitive processes of SI such as phonetic processing, formulation and sequencing of sentences increase cortical thickness, which meets the linguistic requirements of SI.

The effect of different textual features on the $C L$ of expert and novice Slterps has been the focus of many studies in IR. For example, Seeber and Kerzel (2012)suggested that CL increases with asymmetrical syntactic structures and that it is reduced, especially in sentence-final positions, when discourse context is almost fully available to interpreters. Lin et al. (2013) studied non-native accent features such as prosody, syllabification and concluded that they affect the comprehension level of SIterps. The literature has suggested that expert SIterps could develop a maintenance capacity, which allows them to build meaningful connections and that their neural performance is permanently affected by SI activities. There is also a need to explore the effect of textual features on the generalisation of interpreting strategies, especially with language pairs where linearity and constituent symmetry could not be preserved.

\section{The Significance of SISs in Identifying Micro -taxis Relations and Macro Implications}

Kintsch and van Dijk's (1983) basic conception of strategy lays the foundation for interpreting as a strategic "goal-directed activity" that is governed by the cognitive processing of information (Pöchhacker, 2004, p. 132). As such, many interpreting scholars including Kalina identified interpreting strategies as "flexible instruments" in which "the goal determines the amount and thoroughness of processing. It may be consciously used but may also have become automatic in so far as the processor will not have to make any cognitive decision" (Kalina, 1992, p. 253). Of course, strategy is a vast concept, so the focus herein will be limited to intentional goal-oriented mechanisms that Slterps use to manage difficulties arising from input.

A number of studies in IR have investigated different strategic aspects of SI, but anticipation and compression received wider attention as they recorded frequent occurrences by Slterps (Chernov, 1994; Jörg, 1997; Wilss, 1978). Shlesinger's (2000a, 2000b) work on strategies, for example, approached strategies within the framework of interpreter's output and expectancy norms set by Chesterman (1993) due to the cognitive restraints catalysing a strategic response. Kohn and Kalina (2002) proposed a discoursebased mental model that ascribes simultaneous interpreting strategies (SISs) to cognitive-linguistic processes. The model included the main difficulty factors that affect interpreters' performance: speed of delivery, structural complexity, and processing. Thus, a strategy is a certain output standard that benchmarks expert and novice performance and induces a specific recurring experienced solution. Gile addressed strategic and norm-guided practices as "coping tactics" that might be triggered by "rules," with the aim of "maximizing the communication impact of the speech" or "self-protection" (Gile, 1995a, p. 201).

Discourse is a structure and a process that stands for complex phenomena. Structure-based definitions focus on the constituents of a unit of discourse, that is, "language above sentence or above clause" (Stubbs, 1983, p. 1) to demonstrate relationships. As a process, discourse is any aspect of language in its natural conditions that necessitates the accomplishment of a purpose through language use (Fasold, 1990; Roy, 1999; Schiffrin, 1994). Accordingly, the organisation of language impacts its role in building broader social relationships.

More broadly, the concept of regularized interpreting behaviour, better known as simultaneous interpreting strategies, could expand to address a discourse continuum of micro-macro relations in an interpreting activity. Toury (1995) identified three norms to discover SISs: preliminary, which are related to policies of translation and initial, which are concerned with the interpreter's inclination towards adequacy, acceptability, or both. However, a micro-macro strategic development could be better explored through operational norms - the actual linguistic choices and decisions to say, omit, add or segment utterances. The use of corpora could add up to the validity of SISs and to the impact of such strategies on the overall interpretability of discourse. This comes amid a backdrop of SISs as a force that informs interpreters' behaviour and defines equivalence in terms of cultural-linguistic appropriacy rather than prescriptive formalism.

Research has attempted to approach $\mathrm{SI}$ as discourse, focusing on the role of expertise and institutionalisation in framing a micromacro continuum. With institutional power and ideology at the centre of interpreted discourse, "macro-social and microinteractional communicative processes" continually imbricate into one another (Gile, 2004, p. 71). In light of a CDA framework that tackles production and consumption as forms a social practice, Chesterman (1997) identified concepts such as interpreters' flexibility and neutrality as instrumental in conveying the speaker's ideologies. Inghilleri (2003) and Gile (2004) explored the social nature of $\mathrm{SI}$, particularly its institutional character and its broader implications through the alignment of micro and macro dimensions in interpreted discourse based on understanding micro level choices as being significantly active in framing social relations. As a discursive practice and an unstable social encounter that shifts in footing according to the demands of the situation (Goffman, 1983), SI is better explored through "micro-textual approaches ... [because they] share with norm theory a 
recognition that translational activity... includes a sociological, ideological and historical dimension" (Inghilleri, 2003, p.72). Tiselius (2010) analysed the performance of expert Swedish interpreters at European institutions comparing them to survey results submitted by the same interpreters on the institutional nature of AllC- and EU- discourse. The study revealed that accredited interpreters share a strong habitus that fosters collective agreement to institutional regularisation.

As with interpreting cohesive ties and deducing cohesion-specific strategies, Shlesinger (1995) synthesized that interpreting cohesive ties simultaneously is bound with a number of problems including time, insufficient previous exposure to the original topic and linearity-the gradual perception of original discourse by the interpreter as presented in segments rather than complete units of thought. Shifts in cohesive ties occur due to what Slterps conceive of as uninformative information to the listener, so for example, they become prone to omission. Using a formally equivalent cohesive device does not mean that such a device performs the function of the original, accordingly Slterps ought to bridge the gap between surface devices used in the TT and their ST meanings.

The study of problems-in-interpreting helps map out process-oriented strategies (Riccardi, 1996). Analysing authentic interpreting performance of trainee interpreters reveals their awareness of SISs as a concept that would help in overcoming processing problems in Arabic and English. Drawing on that, Shamy and De Pedro Ricoy (2017) used retrospection to allow trainee SIterps to verbalise their perceptions on confusing conjunctive behaviour in an SI event. The study demonstrated ambivalent segmentation that is based on Slterps' different perceptions of the relationship between original units of meaning. More significantly, trainee SIterps showed little awareness of sources of difficulty and minimally reported on the SISs they employed to create a macro discourse effect similar to that of an original conjunctive. Heidar and Biria (2011) studied the functions of conjunctives in a corpus of international law texts using micro and macro analytical methods. They concluded that explicit conjunctives are nonverbal cues with paralinguistic functions that are used as a manoeuvring tool and that referential and structural conjunctives are not as functionally-restricted as cognitive conjunctives, which mainly contribute to elaboration and repair.

Gile (1992), Van Besien, 1999 and Setton (1999) argued that marked grammatical structures will not block interpreting, that is why they criticised a one-way strategies-for-structure approach and rather supported the cognitive-pragmatic processing of linguistic indicators. Pöchhacker (2004) suggested that the segmentation of complex structures could be done pre-emptively through the salami technique (Jones, 1998) or the subunits of sense (Seleskovitch \& Lederer, 1995) in which independent meaningful clause- or phrase-level chunks are divided. Segmentation is directly related to the anticipation strategy, which is the interpreter's ability to interpret a particular sentence-constituent before it is actually produced in the SL. Wilss (1978) divided syntactic anticipation into linguistic and extra-linguistic. Linguistic anticipation is mainly prediction at lexical or structural levels based on a recurrence of specific co-occurring patterns, in other words, strategies. Extra-linguistic anticipation is based on the interpreter's sense of what is right in a given instance.

Live media interpreting of political events with high viewership is reported to be the amongst the most demanding and stressful according to T. Komatsu; the first Japanese TV interpreter, since TV viewers expect Slterps to act as news readers (Ito, 2004). Therefore, media interpreters' training should focus on maintaining a flowy, aesthetic, and natural discourse, which does not exclude the accuracy of content altogether compared to written-to-be-read discourse, but prioritises it to specialized audiences. A corpus analysis of a televised US presidential debate interpreted into German showed that expert SIterps resort to task-related strategies to cope with discourse density, speed and $\mathrm{CL}$, with omission being the most frequent strategy used with reference to cultural-specific items. The generalisation of SISs and their TT-meaning orientation should precede their major impact on decalage adjustment (Pöchhacker, 2004). Magnifico and Defrancq (2016) conducted a micro-macro study to explore how Slterps handle Face-Threatening Acts (FTAs) in a number of speeches taken from the European Parliament Interpreting Corpus. Genderbased findings postulated that for example, male interpreters downtoned FTAs more often than female interpreters and that the act of strengthening original FTAs is four times less than downplaying or altering them. Al-Jabri (2017) analysed a corpus of four televised SI performances of post-Arab Spring presidential speeches with a focus on whether Slterps could convey, downgrade or upgrade the emotive tones of the original. The study adopted a micro-macro framework with the micro focusing on the emotive categories and the SISs used to show emotiveness of the original, and the macro focusing on the political context of the time. The study showed that time and speed resulted in incoherent segments. But in general, a number of SISs were used, with variance, namely, condensation, approximation, generalization, explicitation, omission and paraphrase.

Content-processing or reductive strategies namely, compression and selective omission should be operational in high speed and dense input to decrease repetition (Pöchhacker, 2004). A number of scholars has supported Sense-based transfer as it gives Slterps the freedom to adapt output to cultural specificity and appropriacy. It also creates explicitation, which is an SI strategy utilised to create universals and avoid structural ambiguity and socio-cultural differences. (Dam, 2001; Gran, 1989; Isham, 1994; Kohn \& Kalina, 2002; Viaggio, 1991). Khani and Hadidi (2016) analysed a bidirectional corpus of cultural-bound terms in English and Farsi in sentences and short paragraphs and concluded that total equivalence and specification were the most common SISs 
compared to substitution and rephrasing. Specification expands the context of idiomatic expressions and familiarizes the target audience with the TL.

Diriker (2004) explored SI as a social practice or a sort of situated action to address intercultural aspects of socio-lingual transfer evident in either interpreting. Translation is about "facts of real life" (Toury, 1995, p. 1), in which the advancement of critical social theories and the emergence of real solid concepts lent themselves to relevant political situations and concepts of power, hegemony, ideology, agency and gender.

Since its emergence in the 1950s and flourish in the 1980, scholars of IR were unified to explore quality interpreting parameters, which brought about diverse analyses of SI as a process and a product. Yet, a consensus has not been formed as to which approach is ought to represent IS, such diversity is an asset, therefore "the interpreting research community should not push for greater uniformity of methodological approach but instead turn its diversity into a strength by discovering new relationships and links, thus reinforcing the community's sense of unity and internal coherence" (Pöchhacker, 2014, p. 169). The first research endeavours to tackle SI were process-oriented; psycholinguists were intrigued by the ideas of 'simultaneity' and the complex nature of cognitive processes. Scholars such as (Gerver,1974; Goldman-eisler, 1972) started their exploration with speakinglistening simultaneity and memory-attention span while there was a particular interest in cognitive processing models to map out steps of SI cognitive workings (Gerver, 1976; Moser, 1976; Kirchhoff, 1976a; Roothaer, 1978). Later, Seleskovitch introduced the Interpretive Theory (IT) or the Theory of Sense; a triangular or a three-stage theory that starts with comprehension and ends with reformulation and within which deverbalization stage:

Interpretation is not a direct conversion of the linguistic meaning of the source language to the target language, but a conversion from source language to sense, the intermediate link being nonverbal thought, which, once consciously grasped, can then be expressed in any language regardless of the words used in the original language (Seleskovitch, 1977).

The focus on non-verbal thought rather than the linguistic meaning of the SL reveals the conscious cognitive process that makes it possible to transfer the SL to any TL. Due to words ambiguity and the wide range of meanings at times, a solid context is essential to infer the right sense of a speaker's communicative purpose. The capacity of working memory could, to a great extent, predict interpreting performance including discourse processing and comprehension and concurrent verbal generation of equivalents, a conclusion that is supported by research findings suggesting that in SI, two languages are in constant competition which increases the demand to maintain cognitive control between inter-conflicting pairs and finding an appropriate TT (Craik, 2010; Macnamara and Conway (2016). On the cognitive dimension to pauses, Wang and Li (2014) compiled a corpus of expert interpreting performances to study the nature and reasons of pauses in SI. The results showed that expert SIterps pause to monitor their performance or adopt a certain linguistic strategy such as restructuring. Expert pauses are more appropriate acting as sentential signposts and are fewer than pauses of trainee interpreters.

\section{Conclusions}

The significance of this paper has stemmed from a number of theoretical and hands-on concerns that can give Siterps a new lens to approach SI as a full-fledged social practice with a real societal impact. An original UN discourse is a calculated discourse with embedded positions and ideologies. Since SI is a process that requires the quick processing of content, SIterps usually approach SI in speed, which has its textual and discursive implications. In particular, this property falls short of serving -taxis relations justice as part of a global matrix of relations in discourse in addition to being micro level features that serve a textual function. Expertise is a key parameter to identify SISs, which are the product of different exposures to complicated SI situations and the most suitable solution reached by expert SIterps to overcome operational constraints.

A situational shift occurs every time there is a swing between hypotaxis and parataxis. A situational shift is created by selfinsulation, which is a protection tactic employed by strategic speakers, given that they do not state a definite opinion about an unresolved issue. Another tactic for maintaining power in discourse, though, is to justify parties of priority or interest. In this case, hypotaxis is the stylistic tool used to reach such a strategic goal. Parataxis restricts the deep exposition of positions by which neutrality could not be at stake.

Discourse makers use hypotaxis as a stylistic feature to highlight victimization and accentuate power. For example, selfvictimization can be realised through hypotaxis to show that power and control are not in the hands of a particular group and that even if this less powerful group takes action, the result is beyond its scope of authority. Also, deflection is a tactic employed hypotactically to hide the speaker's fullness through which the speaker maintains control of the situation, giving conditional access to other parties. 
This paper has attempted to provide a comprehensive view of an interdisciplinary paradigm that places simultaneously interpreted discourse is a social practice that intersects with micro features of -taxis relations that could be presented in the following diagram:

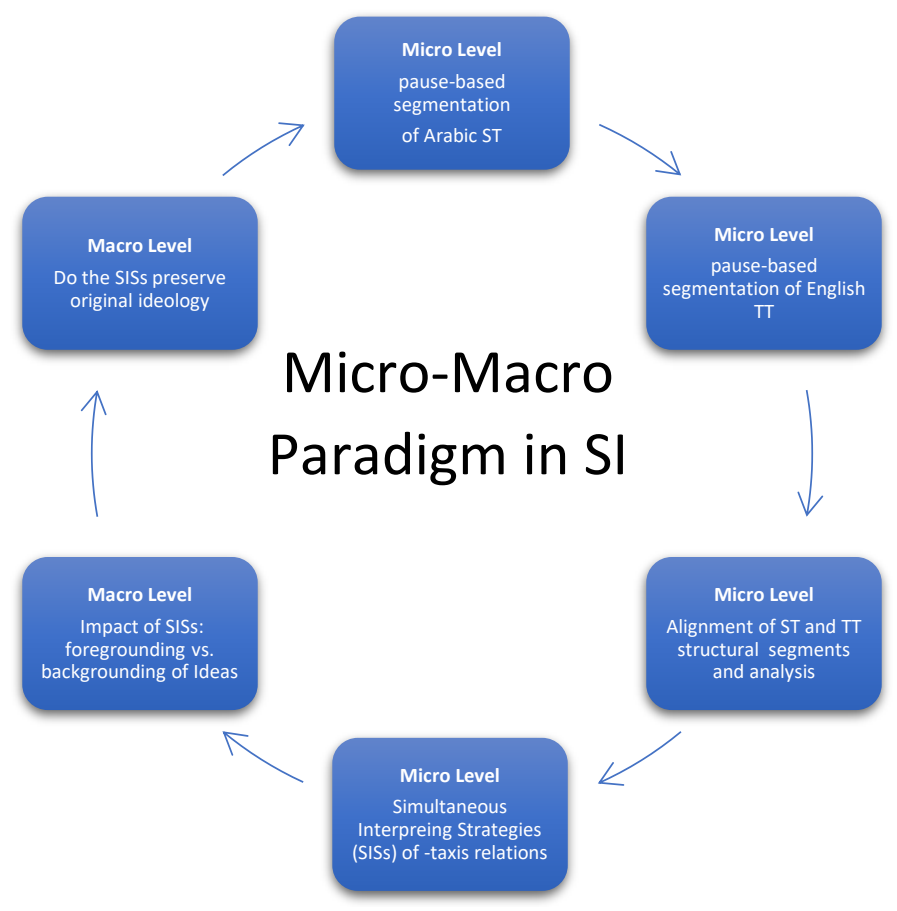

Thus, the main objective of this review is to describe aspects of interpreting with the micro analysis of hypotaxis and parataxis. The general aim is to investigate the impact of $\mathrm{SI}$ at the micro-level in laying bare ideology as conveyed in interpreting performance. This is supposed to generate an important discussion in interpreting pedagogy, assessment and training, and how far it is valuable for interpreters to go beyond the surface structure and establish a broader understanding of meaning relations in various discourses.

\section{References}

[1] Abadi, H. Al. (2015). General Debate: Statemnent of Iraq. https://gadebate.un.org/en/70/iraq

[2] Abboud, P. F., \& McCarus, E. N. (1983). Elementary Modern Standard Arabic. Cambridge University Press.

[3] Al-Jabri, H. (2017). TV Simultaneous Interpreting of Emotive Overtones in Arabic Presidential Political Speeches into English during the Arab Spring. PQDT - Global, 248. https://search.proquest.com/docview/1928502037?accountid=9645

[4] Al-Moualem, W. (2012). General Debate: Statement of Syrian Arab Republic. In UNGA - 67th session. https://gadebate.un.org/en/67/syrianarab-republic

[5] Al-Nahyan, A. B. Z. (2014). General Debate: Statement of United Arab Emirates. https://gadebate.un.org/en/69/united-arab-emirates

[6] Al-Qirbi, A. A. (2011). General Debate: Statement of Yemen. https://gadebate.un.org/en/66/yemen

[7] Al-Sabah, J. A. M. A. H. (2015). General Debate: Statement of Kuwait. https://gadebate.un.org/en/70/kuwait

[8] Al-Thani, T. bin H. (2013). General Debate: Statement of Qatar. https://gadebate.un.org/en/68/qatar

[9] Alazzawie, A. (2014). The Discourse Marker wa in Standard Arabic-A Syntactic and Semantic Analysis. Theory and Practice in Language Studies, 4(10), 2008-2015. https://doi.org/10.4304/tpls.4.10.2008-2015

[10] Aziz, M. O. A. (2014). General Debate: Statement of Mauritania. https://gadebate.un.org/en/69/mauritania

[11] Baddeley, A. d. (2007). Working memory, thought, and action. Oxford University Press. https://doi.org/10.1093/acprof

[12] Baddeley, Alan. (2010). Working memory. Current Biology, 20(4), 136-140. https://doi.org/10.1016/j.cub.2009.12.014

[13] Baker, M. (1992). In Other Words by Mona Baker. Routledge.

[14] Baker, M. (1995). Corpora in Translation Studies: An Overview and Some Suggestions for Future Research. Target, 7(2), $223-243$. https://doi.org/10.1075/target.7.2.03bak

[15] Barranco-Droege, R. (2015). Too fast to be true? Exploring time compression in simultaneous interpreting. Speech Communication, 75, 8496. https://doi.org/10.1016/j.specom.2015.09.009

[16] Beeston, A. F. L. (1970). The Arabic Language Today. In The Modern Language Journal (Vol. 56, Issue 7). Routledge. https://doi.org/10.2307/325118

[17] Binder, M., \& Heupel, M. (2015). The Legitimacy of the UN Security Council: Evidence from Recent General Assembly Debates. International Studies Quarterly, 59(2), 238-250. https://doi.org/10.1111/isqu.12134

[18] Bott, L., Frisson, S., \& Murphy, G. L. (2009). Interpreting conjunctions. Quarterly Journal of Experimental Psychology, 62(4), 681-706. https://doi.org/10.1080/17470210802214866

[19] Charniak, E. (1979). MS. MALAPROP, A LANGUAGE COMPREHENSION PROGRAM. In D. Metzing (Ed.), Frame Conceptions and Text 
Understanding (pp. 1-7). De Gruyter.

[20] Cheng, M. S. (2012). Colin Powell's Speech to the UN: A Discourse Analytic Study of Reconstituted Ethos. Rhetoric Society Quarterly, 42(5), 424-449. https://doi.org/10.1080/02773945.2012.704121

[21] Chernigovskaya, T. V., Parin, S. B., Parina, I. S., Konina, A. A., Urikh, D. K., Yachmonina, Y. O., Chernova, M. A., \& Polevaya, S. A. (2016). Simultaneous interpreting and stress: pilot experiment. International Journal of Psychophysiology, 108, 165. https://doi.org/10.1016/j.ijpsycho.2016.07.472

[22] Chesterman, A. (1993). From "Is" to "Ought": Laws, Norms and Strategies in Translation Studies. Target, 5(1), 1-20. https://doi.org/10.1075/target.5.1.02che

[23] Chesterman, A. (1997). Memes of Translation. John Benjamins.

[24] Childers, E. (1997). The United Nations and global institutions: Discourse and Reality. Global Governance, 3(3), $269-276$.

[25] Cokely, D. (1984). Towards a sociolinguistic model of the interpreting process: ASL and English. Georgetown University.

[26] Dam, H. V. (2001). On the Option Between Form-based and Meaning-based Interpreting: The Effect of Source Text Difficulty on Lexical Target Text Form in Simultaneous Interpreting. The Interpreters' Newsletter, 11, 27-55.

[27] Daniel Gile. (1997). Conference interpreting as a cognitive management problem. In \& M. K. M. In J. H. Danks, G. M. Shreve, S. B. Fountain (Ed.), Cognitive processes in translation and interpreting. Thousand Oaks: Sage Publication.

[28] Davidson, P. M. (1992). Segmentation of Japanese Source Language Discourse in Simultaneous Interpretation. The Interpreters' Newsletter, 1, 2-11.

[29] Dickins, J., Hervey, S., \& Higgins, I. (2017). Thinking Arabic Translation: A course in translation method: Arabic to English (Second). Routledge.

[30] Diriker, E. (2004). De-/Re-Contextualizing Conference Interpreting: Interpreters in the Ivory Tower?

[31] Donahue, R. T., \& Prosser, M. H. (1997). Diplomatic Discourse: International Conflict at the United Nations-- Addresses and Analysis. Ablex Publishing Corporation.

[32] Dong, Y., \& Lin, J. (2013). Parallel processing of the target language during source language comprehension in interpreting. Bilingualism, 16(3), 682-692. https://doi.org/10.1017/S1366728913000102

[33] Dong, Y., \& Zhong, F. (2017). Interpreting experience enhances early attentional processing, conflict monitoring and interference suppression along the time course of processing. Neuropsychologia, 95(February 2016), 193-203. https://doi.org/10.1016/j.neuropsychologia.2016.12.007

[34] Enani, M. (2020). On Translating Style Into Arabic And Into English. Anglo Egyptian Bookshop.

[35] Engelkamp, J., \& Rummer, R. (2002). Subordinating conjunctions as devices for unifying sentences in memory. European Journal of Cognitive Psychology, 14(3), 353-369. https://doi.org/10.1080/09541440143000104

[36] Essid, H. (2015). General Debate: Statement of Tunisia. https://gadebate.un.org/en/70/tunisia

[37] Fahmy, N. (2013). General Debate: Statement of Egypt. https://gadebate.un.org/en/68/egypt

[38] Fairclough, N. (1989). Language and power. In C. N. Candlin (Ed.), New York. Longman.

[39] Fairclough, N. (1992). Discourse and text: linguistic and intertextual analysis within discourse analysis. Discourse \& Society, 3(2), 193-217.

[40] Fairclough, N. (2001). Language and power (second). Taylor \& Francis.

[41] Fairclough, N. (2003). "Political correctness": the politics of culture and language. Discourse \& Society, 14(1), 17-28.

[42] Fairclough, N. (2013). Language and power (second). Routledge.

[43] Fasold, R. (1990). The Sociolinguistics of Language. Blackwell.

[44] Fischhendler, I., \& Katz, D. (2013). The use of "security" jargon in sustainable development discourse: Evidence from UN Commission on Sustainable Development. International Environmental Agreements: Politics, Law and Economics, 13(3), 321-342. https://doi.org/10.1007/s10784-012-9192-z

[45] Gerver, D. (1974). Simultaneous listening and speaking and retention of prose. Quarterly Journal of Experimental Psychology, $26,337-341$. https://doi.org/10.1080/14640747408400422

[46] Gerver, D. (1976). Empirical Studies of Simultaneous Interpretation: A Review and a Model. In R. W. Brislin (Ed.), Translation: applications and research (pp. 165-207). GARDNER PRESS, INC.

[47] Gile, D. (1992). Basic theoretical components in interpreter and translator training. Teaching Translation and Interpreting, 185.

[48] Gile, D. (1995a). Basic Concepts and Models for Interpreter and Translator Training: Revised edition (Benjamins Translation Library). http://www.amazon.com/Concepts-Models-Interpreter-Translator-

Training/dp/9027224331\%3FSubscriptionld\%3D0JYN1NVW651KCA56C102\%26tag\%3Dtechkie20\%26linkCode\%3Dxm2\%26camp\%3D2025\%26creative\%3D165953\%26creativeASIN\%3D9027224331

[49] Gile, D. (1995b). Fidelity Assessment in Consecutive Interpretation. Target. International Journal of Translation StudiesTarget / International Journal of Translation StudiesTarget, 7(1), 151-164. https://doi.org/10.1075/target.7.1.12gil

[50] Gile, D. (1999). Testing the Effort Models' tightrope hypothesis in simultaneous interpreting-A contribution. HERMES-Journal of Language and Communication in Business, 153-172.

[51] Gile, D. (2004). Integrated Problem and Decision Reporting as a Translator Training Tool. The Journal of Specialised Translation, 2, 2-20.

[52] Goffman, E. (1983). American Sociological Association, 1982 Presidential Address. American Sociological Review, 48(1), 1-17.

[53] Goldman-eisler, F. (1972). Segmentation of Input in Simultaneous Translation. Journal of Psycholinguistic Research, 1(2), $127-140$.

[54] Gran, L. (1989). Interdisciplinary research on cerebral asymmetries: Significance and prospects for the teaching of interpretation. In L. Gran \& J. Dodds (Eds.), The Theoretical and Practical Aspects of Teaching Conference Interpretation (pp. 93-100). Campanotto Editore.

[55] Grausam, R. (2005). The Language of Islamic Fundamentalism. AAA: Arbeiten Aus Anglistik Und Amerikanistik, 30(1), $227-241$.

[56] Halliday, M. A. K. (1985). An introduction to functional grammar. Edward Arnold.

[57] Halliday, M. A. K. (1994). An Introduction to Functional Grammar (Second). Edward Arnold.

[58] Halliday, M. A. K., \& Hasan, R. (1976). Cohesion in English. In RELC Journal (Vol. 7, Issue 2). Longman. https://doi.org/10.1177/003368827600700217 
[59] Haspelmath, M. (2004). Coordinating Constructions: an Overview. In M. Haspelmath (Ed.), Coordinating Constructions (Vol. 58, pp. 3-39). John Benjamins Publishing Company.

[60] Heidar, D. M., \& Biria, R. (2011). Sociopragmatic functions of discourse markers in international law texts. Theory and Practice in Language Studies, 1(11), 1479-1487. https://doi.org/10.4304/tpls.1.11.1479-1487

[61] Herschinger, E. (2012). "Hell is the other": Conceptualising hegemony and identity through discourse theory. Millennium: Journal of International Studies, 41(1), 65-90. https://doi.org/10.1177/0305829812449501

[62] Hervais-Adelman, A., Moser-Mercer, B., Murray, M. M., \& Golestani, N. (2017). Cortical thickness increases after simultaneous interpretation training. Neuropsychologia, 98(January), 212-219. https://doi.org/10.1016/j.neuropsychologia.2017.01.008

[63] Holes, C. (2004). Modern Arabic: Structures, functions, and varieties. Georgetown University Press.

[64] Holzscheiter, A. (2011). Power of discourse or discourse of the powerful? Journal of Language and Politics, 10(1), 1-28. https://doi.org/10.1075/jlp.10.1.01hol

[65] Huddleston, R., Payne, J., Peterson, P., \& Pullum, G. K. (2002). Coordination and Supplementation. In The Cambridge Grammar of the English Language (pp. 1273-1362). Cambridge University Press.

[66] Huddleston, Rodney. (1988). English Grammar: An Outline (Vol. 23, Issue 4). Cambridge University Press. https://doi.org/10.2307/3587546

[67] Huddleston, Rodney, \& Pullum, G. K. (2007). A student's introduction to English grammar (third). Cambridge University Press.

[68] Inghilleri, M. (2003). Habitus, field and discourse: Interpreting as a socially situated activity. Target. International Journal of Translation Studies, 15(2), 243-268. https://doi.org/10.1075/target.15.2.03ing

[69] Ingram, R. (1974). A communication model of the interpreting process. Journal of Rehabilitation of the Deaf, 7, 3-9.

[70] Ingram, R. M. (1985). Simultaneous interpretation of sign languages: Semiotic and psycholinguistic perspectives. Multilingua, 4(2), 91-102. https://doi.org/10.1515/mult.1985.4.2.91

[71] Injoque-Ricle, I., Barreyro, J. P., Formoso, J., \& Jaichenco, V. I. (2015). Expertise, working memory and articulatory suppression effect: Their relation with simultaneous interpreting performance. Advances in Cognitive Psychology, 11(2), 56-63. https://doi.org/10.5709/acp-0171-1

[72] Interpreting Volume 2 issue 1-2 1997 [doi 10.1075_intp.2.1-2.02mas] Massaro, Dominic W.; Shlesinger, Miriam -- Information processing and a computational approach to the study of simultaneous interp.pdf. (n.d.).

[73] Isham, W. P. (1994). Memory for sentence form after simultaneous interpretation: Evidence both for and against deverbalization. In Sylvie Lambert \& B. Moser-Mercer (Eds.), Bridging the Gap: Empirical research in simultaneous interpretation (pp. 191-211). John Benjamins.

[74] Ito, M. (2004). TATSUYA KOMATSU Simultaneously interpreting both language and culture. The Japan Times. https://www.japantimes.co.jp/life/2004/05/09/to-be-sorted/simultaneously-interpreting-both-language-and-culture/

[75] Jones, R. (1998). Conference Interpreting Explained. St. Jerome.

[76] Jörg, U. (1997). Bridging the Gap: Verb Anticipation in German-English Simultaneous Interpreting. In M. Snell-Hornby, Z. Jettmarová, \& K. Kaindl (Eds.), Translation As Intercultural Communication Benjamins Translation Library (pp. 217-228). John Benjamins.

[77] Jørgensen, M. W., \& Phillips, L. J. (2002). Discourse Analysis as Theory and Method. Sage Publications Ltd.

[78] Kalina, S. (1992). Discourse Processing and Interpreting Strategies: An Approach to the Teaching of Interpreting. In C. Dollerup \& A. Loddegaard (Eds.), Teaching Translation and Interpreting: Training, Talent and Experience (Vol. 5, Issue 2, pp. 251-257). John Benjamins. https://doi.org/10.1075/target.5.2.10wei

[79] Khani, F. H. A., \& Hadidi, Y. (2016). A Comparative Study of Interpretation Strategies Applied by Tabriz Professional Simultaneous Interpreters in Dealing with Culture-bound Terms. Theory and Practice in Language Studies, 6(1), 164. https://doi.org/10.17507/tpls.0601.21

[80] Kohn, K., \& Kalina, S. (2002). The Strategic Dimension of Interpreting. Meta, 41(1), 118-138. https://doi.org/10.7202/003333ar

[81] Köpke, B., \& Signorelli, T. M. (2012). Methodological aspects of working memory assessment in simultaneous interpreters. International Journal of Bilingualism, 16(2), 183-197. https://doi.org/10.1177/1367006911402981

[82] Lang, E. (1984). The semantics of coordination. https://www.justbooks.fr/search/?keywords=90+272+3008+0\&currency=EUR\&destination=fr\&mode=isbn\&lang=fr\&st=sh\&ac=qr\&subm it $=$

[83] le Roux, K., \& Adler, J. (2016). A critical discourse analysis of practical problems in a foundation mathematics course at a South African university. Educational Studies in Mathematics, 91(2), 227-246. https://doi.org/10.1007/s10649-015-9656-5

[84] Lehmann, C. (1988). Towards a typology of clause linkage. In J. Haiman \& S. A. Thompson (Eds.), Clause Combining in Grammar and Discourse (pp. 181-226). John Benjamins Publishing Company.

[85] Lin, I. H. I., Chang, F. L. A., \& Kuo, F. L. (2013). The impact of non-native accented English on rendition accuracy in simultaneous interpreting. Translation and Interpreting, 5(2), 30-44. https://doi.org/10.12807/ti.105202.2013.a03

[86] Long, D., \& Woolley, F. (2009). Global Public Goods: Critique of a UN Discourse. Global Governance, 15(1), $107-122$.

[87] Macnamara, B. N., \& Conway, A. R. A. (2016). Working Memory Capacity as a Predictor of Simultaneous Language Interpreting Performance. Journal of Applied Research in Memory and Cognition, 5(4), 434-444. https://doi.org/10.1016/j.jarmac.2015.12.001

[88] Magnifico, C., \& Defrancq, B. (2016). Impoliteness in interpreting: A question of gender? Translation and Interpreting, 8(2), 26-45. https://doi.org/10.12807/ti.108202.2016.a03

[89] McEntee-Atalianis, L. J. (2011). The role of metaphor in shaping the identity and agenda of the United Nations: The imagining of an international community and international threat. Discourse and Communication, 5(4), 393-412. https://doi.org/10.1177/1750481311418099

[90] Monte, I. X. do. (2016). The Pen is Mightier than the H-Bomb. Interventions, 18(5), 669-686.

[91] Moser-Mercer, B. (2000). Simultaneous interpreting: Cognitive potential and limitations. Interpreting, 5(2), 83-94. https://doi.org/10.1075/intp.5.2.03mos

[92] Nida, E. A. (1964). Toward a Science of Translating with Special Reference to Principles and Procedures Involved in Bible Translating. Brill.

[93] Panke, D. (2014). The UNGA—a talking shop? Exploring rationales for the repetition of resolutions in subsequent negotiations. In Cambridge Review of International Affairs (Vol. 27, Issue 3, pp. 442-458). Taylor \& Francis. https://doi.org/10.1080/09557571.2014.931354

[94] Pöchhacker, F. (2004). Introducing interpreting studies. In Perspectives (Vol. 27, Issue 1). Routledge. 
https://doi.org/10.1080/0907676x.2018.1525009

[95] Pöchhacker, F. (2014). Unity in Diversity: The Case of Interpreting Studies. In L. Bowker, Michael Cronin, D. Kenny, \& J. Pearson (Eds.), Unity in Diversity? Current Trends in Translation Studies (pp. 169-176). Routledge.

[96] Prof, A., \& ljam, D. M. M. (2013). Complex and Compound Sentences in English-Arabic Translation Complex and Compound Sentences in English-Arabic Translation.

[97] Radu, R. (2013). Negotiating meanings for security in the cyberspace. Info, 15(6), 32-41. https://doi.org/10.1108/info-04-2013-0018

[98] Riccardi, A. (1996). Language specific strategies in simultaneous interpreting. (pp. 213-222). In C. Dollerup \& V. Appel (Eds.), Teaching translation and interpreting 3 (Vol. 16, pp. 213-222). John Benjamins. https://doi.org/10.1075/target.9.2.17gad

[99] Rinne, J. O., Tommola, J., Laine, M., Krause, B. J., Schmidt, D., Kaasinen, V., Tera, M., \& Sipila, H. (2000). The translating brain: cerebral activation patterns during simultaneous interpreting. 294, 85-88.

[100]Roy, C. (1999). Interpreting as a Discourse Process. Oxford University Pressfile:///D:/hard drive/phd/data/literature review/1 data/books/interpreting/[Gideon_Toury]_Descriptive_Translation_Studies__a(BookFi).pdf.

[101]Salam, T. (2014). General Debate: DStatement of Lebanon. https://gadebate.un.org/en/69/lebanon

[102]Sawyer, D. B. (2004). Fundamental Aspects of Interpreter Education (Vol. 53, Issue 9). John Benjamins Publishing Company.

[103]Schiffrin, D. (1994). Approaches to Discourse. Blackwell.

[104]Schnurr, S., Homolar, A., Macdonald, M. N., \& Rethel, L. (2014). Legitimizing claims for 'crisis' leadership in global governance: The discourse of nuclear non-proliferation. Critical Discourse Studies, 12(2), 187-205. https://doi.org/10.1080/17405904.2014.974636

[105]Scotto di Carlo, G. (2015). "Weasel Words" in Legal and Diplomatic Discourse: Vague Nouns and Phrases in UN Resolutions Relating to the Second Gulf War. International Journal for the Semiotics of Law, 28(3), 559-576. https://doi.org/10.1007/s11196-015-9406-0

[106]Seeber, K. G. (2015). Simultaneous Interpreting. In H. Mikkelson \& R. Jourdenais (Eds.), Routledge handbook of interpreting (Vol. 1, pp. 7996). Taylor and Francis. https://doi.org/10.1075/intp.17.1.06see

[107]Seeber, K. G., \& Kerzel, D. (2012). Cognitive load in simultaneous interpreting: Model meets data. International Journal of Bilingualism, 16(2), 228-242. https://doi.org/10.1177/1367006911402982

[108]Seleskovitch, D., \& Lederer, M. (1995). A systematic approach to teaching interpretation (trans. J. Harmer). Silver Spring, MD: Registry of Interpreters for the Deaf.

[109]Seleskovitch, Danica. (1977). Why Interpreting is not Tantamount to Translating Languages. The Incorporated Linguist, 16(2).

[110]Setton, R. (1999). Simultaneous Interpretation: A Cognitive-Pragmatic Analysis. John Benjamins.

[111]Shamy, M., \& De Pedro Ricoy, R. (2017). Retrospective protocols: Tapping into the minds of interpreting trainees. Translation and Interpreting, 9(1), 51-71. https://doi.org/10.12807/ti.109201.2017.a05

[112]Sharon O 'Brien. (2015). The borrowers: Researching the cognitive aspects of translation. In S. G. S. O ' b. Maureen Ehrensberger-Dow (Ed.), Interdisciplinarity in Translation and Interpreting Process Research (Vol. 72, pp. 5-17). John Benjamins B.V.

[113]Shepherd, L. J. (2015). Constructing civil society: Gender, power and legitimacy in United Nations peacebuilding discourse. European Journal of International Relations, 21(4), 887-910. https://doi.org/10.1177/1354066115569319

[114]Shlesinger, M. (1995). Shifts in cohesion in simultaneous interpreting. Translator, 1(2), 193-214. https://doi.org/10.1080/13556509.1995.10798957

[115]Shlesinger, M. (2000). Evaluation Issues in Interpreting. The Translator, 6(2), 363-366. https://doi.org/10.1080/13556509.2000.10799075

[116]Simon-Vandenbergen, A.-M., White, P. R. R., \& Aijmer, K. (2007). Presupposition and 'taking-for-granted' in mass communicated political argument. In A. Fetzer \& G. E. Lauerbach (Eds.), Political Discourse in the Media: Cross-cultural perspectives (pp. 31-47). John Benjamins.

[117]Strobach, T., Becker, M., Schubert, T., \& Kühn, S. (2015). Better dual-task processing in simultaneous interpreters. Frontiers in Psychology, 6(OCT), 1-9. https://doi.org/10.3389/fpsyg.2015.01590

[118]Stubbs, M. (1983). Discourse Analysis: The sociolinguistic analysis of Natural Language. University of Chicago Press.

[119]Thérien, J. P., \& Dumontier, M. B. (2009). The United Nations and global democracy: From discourse to deeds. Cooperation and Conflict, 44(4), 355-377. https://doi.org/10.1177/0010836709344447

[120]Thérien, J. P., \& Joly, P. (2014). "All human rights for all": The United Nations and human rights in the post-Cold War era. Human Rights Quarterly, 36(2), 373-396. https://doi.org/10.1353/hrq.2014.0018

[121]Tiselius, E. (2010). A Sociological Perspective on Expertise in Conference Interpreting: A case study on Swedish Conference Interpreters. Interpreting, December 2008, 1-24.

[122]Toury, G. (1995). Descriptive Translation Studies - and beyond. John Benjamins.

[123]Trask, R. L. (1993). A dictionary of grammatical terms in linguistics (Vol. 94, Issue 4). https://doi.org/10.1016/0024-3841(94)90013-2

[124]Tzou, Y. Z., Eslami, Z. R., Chen, H. C., \& Vaid, J. (2012). Effect of language proficiency and degree of formal training in simultaneous interpreting on working memory and interpreting performance: Evidence from Mandarin-English speakers. International Journal of Bilingualism, 16(2), 213-227. https://doi.org/10.1177/1367006911403197

[125]UN. (2000). Millennium Declaration. Millennium Declaration Report. https://www.ohchr.org/EN/Professionallnterest/Pages/Millennium.aspx

[126]Van Besien, F. (1999). Anticipation in Simultaneous Interpretation. Meta, 44(2), 250-259. https://doi.org/10.7202/004532ar

[127]Van Dijk, T. A. (1991). Racism and the Press. In News As Discourse. Routledge. https://doi.org/10.4324/9780203062784

[128]van Dijk, T. A., \& Kintsch, W. (1983). Strategies of Discourse Comprehension. Academic Press. https://doi.org/10.2307/415483

[129]Van Dijk Teun A. (1988). News as Discourse. In The International Encyclopedia of Communication. Lawrence Erlbaum Associates, Inc. https://doi.org/10.1002/9781405186407.wbiecn020

[130]Van Dijk Teun A. (1995). Discourse semantics and ideology. Discourse \& Society, 6(2), 243-289.

[131]Viaggio, S. (1991). Teaching Beginners to Shut Up and Listen. The Interpreters' Newsletter, 4, 45-58.

[132]Wilss, W. (1978). Syntactic Anticipation in German-English Simultaneous Interpreting. In D. Gerver (Ed.), Language interpretation and communication (pp. 343-352). Plenum Press. 